\title{
PENERAPAN METODE EKSTRAKSI PELARUT DALAM PEMISAHAN MINYAK ATSIRI JAHE MERAH (Zingiber officinale Var.Rubrum)
}

\section{[The Application of Solvent Extraction Method in The Separation of Red Ginger A Volatile Oil (Zingiber officinale Var. rubrum)]}

\author{
Nina Rahmadani ${ }^{1^{\star}}$, Ruslan ${ }^{1}$, Pasjan Satrimafitrah ${ }^{1}$ \\ 1 Jurusan Kimia Fakultas MIPA, Universitas Tadulako \\ Jl. Soekarno Hatta Km.9, Kampus Bumi Tadulako Tondo Palu, Telp. 0451- 422611
}

*)Coresponding author: ninarahmadani92@gmail.com

Diterima 26 Februari 2018, Disetujui 27 Maret 2018

\begin{abstract}
A research on the application of solvent extraction method in the separation of red ginger, a volatile oil (Zingiber officinale Var.rubrum) has been conducted. The purpose of this research is to determine the ratio of $n$-hexane solvent to red ginger powder which produce red ginger volatile extract with high yield and red ginger volatile oil compound components. This research used Completely Randomized Design (RAL). The applied treatment was the influence of the $n$-hexane solvent ratio to the red ginger powder comprising five ratios of $1: 7,1: 8,1: 9,1: 10$, and 1:11 (w/v) with two repetitions. The parameters observed were yield of red ginger volatile oil extract. The results showed that the highest yield of red ginger oil extract was $6.695 \%$ at ratio of $1: 11$. Analysis of GC-MS of red ginger volatile oil show that there are 6 components of the compound produced.
\end{abstract}

Keywords : Ginger volatile Oil, Extraction, Gas Chromatography-Mass Spectrophotometry (GC-MS)

\begin{abstract}
ABSTRAK
Telah dilakukan penelitian tentang penerapan metode ekstraksi pelarut dalam pemisahan minyak atsiri jahe merah (Zingiber officinale Var.rubrum). Tujuan penelitian ini adalah untuk mengetahui rasio pelarut $n$-heksan terhadap serbuk jahe merah yang menghasilkan ekstrak minyak atsiri jahe merah dengan rendemen yang tinggi dan komponen senyawa minyak atsiri jahe merah. Penelitian ini menggunakan Rancangan Acak Lengkap (RAL). Perlakuan yang diterapkan adalah pengaruh rasio pelarut $n$-heksan terhadap serbuk jahe merah yang terdiri atas lima perbandingan rasio yaitu 1:7, 1:8, 1:9, 1:10, dan 1:11 (b/v) dengan dua kali pengulangan. Parameter yang diamati adalah rendemen ekstrak minyak atsiri jahe merah. Hasil penelitian menunjukkan bahwa rendemen ekstrak minyak atsiri jahe merah yang tertinggi tardapat pada rasio $1: 11$ sebesar 6,695\%. Analisis GC-MS minyak atsiri jahe merah menunjukkan bahwa terdapat 6 komponen senyawa yang dihasilkan.
\end{abstract}

Kata Kunci : Minyak Atsiri Jahe, Ekstraksi, Gas Cromatography-Mass Spektrofotometri (GC-MS) 


\section{LATAR BELAKANG}

Kemajuan ilmu pengetahuan dan teknologi menyebabkan semakin meningkatnya usaha untuk mengetahui cara memperoleh minyak atsiri dan pendayagunaannya dalam kehidupan manusia. Minyak atsiri dapat diisolasi dari berbagai jenis tanaman, salah satunya dengan cara penyulingan (Rumondang, 2004). Salah satu tanaman penghasil minyak atsiri tersebut adalah rimpang jahe merah. Jahe merah (Zinggiber officinale var. rubrum) merupakan salah satu tanaman khas di Indonesia. Kandungan oleoresin pada rimpang jahe merah akan memberikan rasa pedas, sedangkan minyak atsiri di dalamnya akan menghasilkan aroma yang khas. Minyak atsiri jahe dimanfaatkan sebagai bahan kosmetik, parfum, dan aroma terapi pada industri farmasi, pada industri makanan digunakan sebagai bahan penyedap (Wulandari, 2010).

Minyak atsiri jahe merah dapat diperoleh dengan cara ekstraksi ataupun penyulingan. Metode penyulingan merupakan metode yang paling umum digunakan oleh para petani di Indonesia karena tidak menggunakan pelarut kimia dan lebih mudah untuk dilakukan (Budi, 2009). Namun pada kali ini metode yang digunakan untuk mengambil minyak atsiri jahe merah adalah metode ekstraksi, karena metode ekstraksi juga dapat menghasilkan produk-produk olahan jahe seperti minyak atsiri jahe.
Beberapa peneliti telah melakukan metode ekstraksi minyak atsiri jahe dengan menggunakan teknik-teknik baru, diantaranya menggunakan karbondioksida $\left(\mathrm{CO}_{2}\right)$ dan etanol sebagai pelarut untuk mengekstrak jahe Australia (Badalyan et al., 1998 dalam Djafar 2010), , menggunakan metode Microwave Assisted Extraction (MAE) (Kurniasari, 2008 dan Purwanto, 2010). Purwanto (2010) melaporkan bahwa salah rasio pelarut terhadap bahan baku sangat berpengaruh terhadap rendemen minyak atsiri.

Penggunaan metode ekstraksi melalui teknik-teknik baru tersebut, tentunya membutuhkan biaya yang sangat mahal untuk melakukannya. Akan tetapi untuk memudahkan penelitian dengan metode ekstraksi, maka salah satu alternatif yang diambil adalah menggunakan metode ekstraksi pelarut secara maserasi. Hal ini dikarenakan teknik pengerjaan dan alat yang digunakan sederhana dan sesuai untuk mengekstrak senyawa yang bersifat tidak tahan panas, seperti minyak atsiri jahe. Dengan demikian, perlu dilakukan penelitian mengenai penerapan metode ekstraksi pelarut dalam pemisahan minyak atsiri jahe merah (Zingiber officinale var. rubrum).

\section{METODE PENELITIAN}

\section{Bahan dan Peralatan}

Bahan dasar yang digunakan dalam penelitian ini adalah rimpang jahe merah, 
bahan lainnya adalah $n$-heksan, etanol $96 \%$, kertas saring dan aluminium foil.

Peralatan yang digunakan dalam penelitian ini meliputi neraca analitik, rotari vakum evaporator, GCMS-QP2010S Shimadzu, blender, ayakan 40 mesh dan alat-alat gelas yang umum digunakan dalam Laboratorium Kimia.

\section{Prosedur Kerja}

\section{Persiapan Sampel Jahe merah}

Rimpang jahe merah dibersihkan dan diiris tipis kemudian dikeringanginkan, lalu diblender untuk mendapatkan serbuk kasar jahe merah. Setelah itu, serbuk jahe tersebut diayak dengan menggunakan ayakan 40 mesh, sehingga diperoleh serbuk halus rimpang jahe merah.

\section{Ekstraksi Minyak Atsiri Jahe Merah}

Serbuk halus rimpang jahe merah diekstrak secara maserasi menggunakan pelarut $n$-heksan (modifikasi metode Damayanti dan Fitriana, 2012). Perbandingan antara serbuk jahe merah dengan pelarut $n$-heksan dijadikan sebagai perlakuan dengan lima tingkatan rasio, masing-masing $1: 7,1: 8,1: 9,1: 10$ dan 1:11. Dimana 1 adalah bagian serbuk jahe merah, 7, 8, 9, 10 dan 11 adalah bagian pelarut $n$-heksan atas dasar berat/volum (b/v). Serbuk rimpang jahe merah dimasukkan ke dalam wadah ekstraksi sebanyak $100 \mathrm{~g}$, kemudian ditambahkan pelarut $n$-heksan sesuai perlakuan. Campuran didiamkan selama 6 jam sambil sekali-kali diaduk, selanjutnya didiamkan hingga 24 jam. Campuran disaring untuk memisahkan ekstrak dari residu jahe merah. Ekstrak yang dihasilkan dipekatkan secara vakum menggunakan rotari vakum evaporator hingga diperoleh ekstrak pekat kemudian ditimbang untuk mengetahui rendemennya. Ekstrak pekat tersebut diekstraksi kembali dengan etanol 96\% sebanyak tiga kali. Perbandingan ekstrak dengan etanol adalah 1:2 (v/v). Ekstrak etanol diuapkan pelarutnya secara vakum menggunakan rotari vakum evaporator hingga diperoleh ekstrak pekat minyak atsiri jahe merah kemudian ekstrak pekat dianalisis komponen senyawanya menggunakan metode GC-MS.

\section{Penentuan Rendemen Minyak Atsiri}

Rendemen minyak atsiri jehe merah yang dihasilkan ditentukan menggunakan persamaan sebagai berikut:

Rendemen $(\%)=\frac{\text { berat sampel minyak }(\mathrm{g})}{\text { berat sampel }(\mathrm{g})} \times 100 \%$

\section{Analisis Senyawa Dalam Minyak Atsiri Jahe Merah Menggunakan GC-MS (Hustany, 1999).}

Minyak jahe merah (Zingiber officinale var. rubrum) dianalisis komponen senyawanya dengan menggunakan metode GC-MS (Gas ChromatographyMass Spectrometry). Cara pelaksanaannya sebagai berikut, peralatan GC-MS yang akan digunakan untuk GC diprogram pada suhu $60^{\circ} \mathrm{C}$ selama 4 menit, kemudian dinaikkan suhunya menjadi $120^{\circ} \mathrm{C}$ dengan kenaikan suhu $2^{\circ} \mathrm{C}$ per menit. Pada suhu $120^{\circ} \mathrm{C}$ dipertahankan selama 5 menit, kemudian dinaikkan lagi 
suhunya dengan kenaikan suhu $50^{\circ} \mathrm{C}$ per menit sampai suhu akhir $290^{\circ} \mathrm{C}$ dan dipertahankan selama 10 menit. Laju aliran gas total yang digunakan adalah $50 \mathrm{ml}$ per menit dengan slit ratio 1:3 suhu injector $300^{\circ} \mathrm{C}$ dan jumlah sampel disuntikkan ke injektor sebanyak $0,1 \mu \mathrm{I}$. MS yang digunakan memiliki energi elektron sebesar 70 eV dengan accelerating voltage sebesar $1,30 \mathrm{kV}$. Mass range yang dideteksi berkisar antara 40-400 dengan interval scanning 1 detik dan resolusi sebesar 1.000 .

\section{HASIL DAN PEMBAHASAN}

\section{Rendemen Ekstrak Minyak Jahe Merah Pada berbagai Rasio Pelarut n-Heksan}

Rendemen minyak atsiri jahe merah merupakan salah satu bagian yang berpengaruh pada kadar minyak atsiri jahe merah. Hasil rata-rata rendemen minyak atsiri jahe merah yang dihasilkan dari proses ekstraksi secara maserasi dengan pelarut $n$-heksan dapat dilihat pada Gambar 1. Hasil pengamatan rendemen minyak atsiri jahe merah pada berbagai rasio pelarut $n$-heksan terhadap serbuk jahe merah (Gambar 1) menunjukkan makin tinggi penggunaan $n$-heksan, makin tinggi pula rendemen minyak atsiri jahe merah yang dihasilkan.

Hasil rendemen tertinggi yang diperoleh terdapat pada rasio 1:11 sebesar $6,695 \%$ dan yang terendah adalah $4,775 \%$ pada rasio 1:7. Perolehan rendemen meningkat dengan meningkatnya rasio pelarut $n$-heksan terhadap serbuk jahe merah. Hal tersebut disebabkan karena faktor kelarutan minyak atsiri jahe dalam serbuk jahe merah terhadap pelarut $n$ heksan. Makin banyak pelarut yang digunakan makin tinggi pula minyak atsiri jahe yang terlarut atau yang terekstrak.

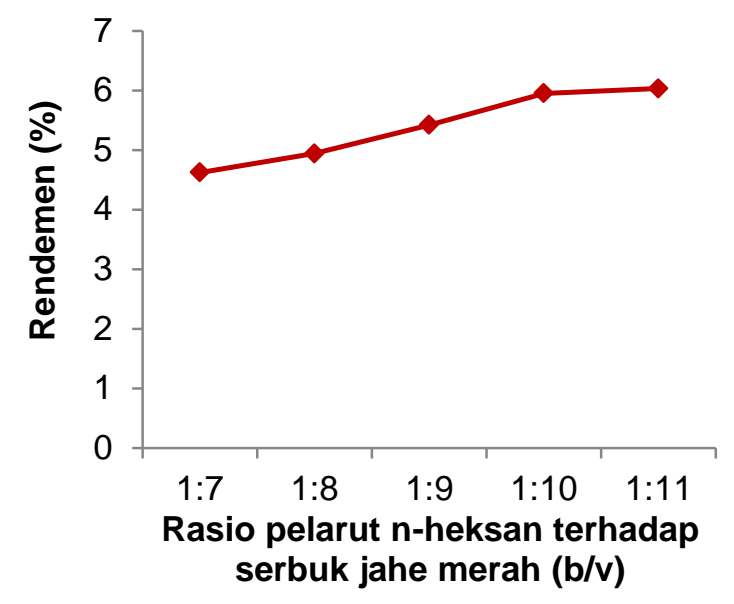

Gambar 1 Grafik Hubungan Rasio Pelarut nHeksan Terhadap Serbuk Jahe Merah Dengan Rendemen Ekstrak Minyak Atsiri Jahe Merah

Rendemen minyak atsiri yang dihasilkan dalam penelitian ini lebih baik jika dibandingkan dengan rendemen minyak atsiri jahe merah yang dihasilkan menggunakan metode penyulingan uap dan air sebesar 0,284 \% yang dilakukan oleh Fatriani (2007) dengan jumlah sampel jahe adalah $60 \mathrm{~kg}$, setiap sekali penyulingan digunakan sampel seberat 4 kg selama 6 jam. Pada penelitian ini hanya menggunakan jumlah sampel jahe seberat $1 \mathrm{Kg}$, dan setiap kali ekstraksi digunakan sampel seberat $100 \mathrm{~g}$ selama 24 jam yang tentunya menghasilkan rendemen yang lebih tinggi dibandingkan rendemen minyak atsiri yang diperoleh Fatriani (2007).

Lain halnya pada penelitian Purwanto (2010), yang melakukan proses 
produksi minyak jahe menggunakan teknologi Microwave Assisted Extraction (MAE), dari penelitiannya menunjukkan bahwa hasil rendemen tertinggi dicapai pada ekstraksi dengan rasio pelarut-bahan baku 8:1. Ekstraksi dengan rasio pelarutbahan baku lebih besar dari 8:1 menghasilkan perolehan ekstrak yang lebih rendah. Menurut Purwanto (2010), hal itu mungkin disebabkan pada rasio pelarut-bahan baku yang lebih tinggi, volume pelarut jauh lebih banyak, demikian juga dengan volume air yang terdapat didalam campuran pelarut.

Hasil analisis sidik ragam yang diplakukan menunjukkan bahwa rasio pelarut $n$-heksan terhadap serbuk jahe merah berpengaruh terhadap rendemen minyak atsiri jahe merah yang ditandai dengan nilai signifikan $0,042<\alpha(0,05)$. Analisis lanjut dengan uji Duncan memberikan keterangan rendemen minyak atsiri jahe pada rasio 1:11 berbeda dengan rasio $1: 8$ dan $1: 7$, sedangkan $1: 10$ dan $1: 9$ tidak berbeda.

\section{Komponen Senyawa Kimia Minyak Atsiri Jahe Merah}

Analisis komponen senyawa minyak atsiri merupakan bagian yang penting dalam industri minyak atsiri untuk menentukan nilai mutu dan tingkat harga suatu minyak. Komponen kimia minyak atsiri jahe merah dianalisis menggunakan metode Gas Chromatography-Mas Spectrometry (GC-MS) atau Kromatografi Gas Spektrofotometer Massa (KG-SM)
(Winarsi, 2014). Analisis profil aroma minyak atsiri dengan KG-SM lebih tepat karena untuk menganalisis minyak diperlukan dua tahapan pemisahan komponen campuran dalam sampel yaitu melalui kromatografi gas (KG) sedangkan tahap selanjutnya yaitu analisis dengan spektrofotometer massa (SM) yang berfungsi untuk mendeteksi masingmasing molekul komponen yang dipisahkan pada sistem krometografi gas (Wulandari, 2010). Adapun hasil analisis GC-MS yang diperoleh pada minyak atsiri jahe merah dalam penelitian ini dapat ditunjukkan pada Gambar 2.

Pada Gambar 2 menunjukkan bahwa hasil analisis GC-MS minyak atsiri jahe merah yang diperoleh melalui ekstraksi pelarut secara maserasi terlihat 6 puncak yang menunjukkan bahwa terdapat 6 komponen senyawa kimia yang ada pada minyak atsiri jahe merah yang dihasilkan. Luas area puncak yang ada relatif berbeda, demikian pula dengan komponen senyawa kimia yang dihasilkan (Tabel 1).

Berdasarkan analisis GC-MS, minyak atsiri jahe merah mengandung komponen senyawa kimia yang tertinggi terdapat pada puncak ke 3 yaitu zingiberene (31,47\%), lalu diikuti oleh 1-metil-4-(5metilheksan-2 il)Benzen (22,46\%), ВSesquiphellandren (21,51\%), B-Bisabolene $(14,62 \%)$, Fernesene $(7,70 \%)$ dan yang paling rendah adalah Geranyl Acetate $(2,24 \%)$. Komponen senyawa kimia yang dihasilkan dalam penelitian ini memiliki jumlah yang lebih banyak dibandingkan 
dengan hasil penelitian Djafar (2010), berbeda di antaranya zingiberene, namun terdapat 3 senyawa yang sama fernesene dan B-Sesquiphellandrene. yang dihasilkan dengan jumlah \% yang

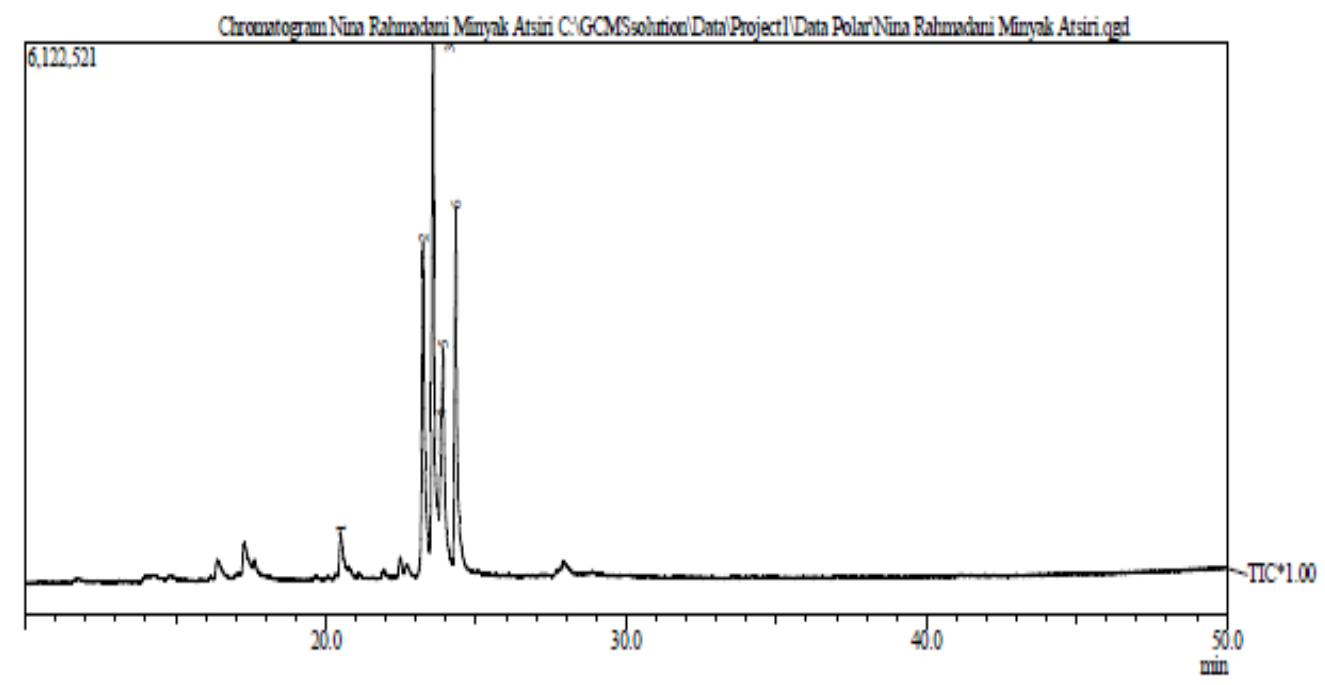

\begin{tabular}{|c|c|c|c|c|c|c|}
\hline & & & & & \multicolumn{2}{|c|}{ Peak Repurt IC } \\
\hline Peadi F & RTime & I.Time & F.Time & Area & Area $\%$ & Height Name \\
\hline 1 & 20.485 & 20.408 & 20.583 & 2245990 & 224 & 395004 \\
\hline 2 & 23.237 & 23.125 & 23.433 & 22536257 & 22.46 & 3450411 \\
\hline 3 & 23.570 & 23.433 & 23.708 & 31581228 & 31.47 & 5577562 \\
\hline 4 & 23.833 & 23.708 & 23.850 & 7732041 & 7.70 & 1564969 \\
\hline 5 & 23.902 & 23.850 & 24.150 & 14669894 & 14.62 & 2306035 \\
\hline 6 & 24.321 & 24.150 & 24.600 & 21591670 & 21.51 & 3772600 \\
\hline & & & & 100357080 & 100.00 & 17074671 \\
\hline
\end{tabular}

Gambar 2 Spektrum GC-MS minyak atsiri jahe merah

Tabel 1 Komponen Senyawa Hasil analisis GCMS minyak atsiri jahe merah

\begin{tabular}{llccc}
\hline No. $\begin{array}{l}\text { Nama } \\
\text { Senyawa }\end{array}$ & $\begin{array}{c}\text { Waktu } \\
\text { Retensi }\end{array}$ & Area & $\begin{array}{c}\% \\
\text { Area }\end{array}$ \\
\hline 1. & $\begin{array}{l}\text { Geranyl } \\
\text { Acetate }\end{array}$ & 20,485 & 2245990 & 2,24 \\
& $\begin{array}{l}1-\text { metil-4-(5- } \\
\text { metilheksan- }\end{array}$ & 23,237 & 22536257 & 22,46 \\
& 2 il)Benzen \\
3. & Zingiberene & 23,570 & 31581228 & 31,47 \\
4. & Fernesene & 23,833 & 7732041 & 7,70 \\
5. & B-Bisabolene & 23,902 & 14669894 & 14,62 \\
6. & $\begin{array}{l}\text { B-Sesqui } \\
\text { phellandren }\end{array}$ & 24,321 & 21591670 & 21,51 \\
\hline
\end{tabular}

Penelitian Djafar (2010), yang menggunakan metode hidrodistilasi sistem kohobasi terdapat 5 komponen kimia minyak jahe hasil analisa GC-MS yaitu arCurcumene (19,72\%), Zingiberene (14,13\%),
B-Sesquiphellandrene (13,49\%), Farnesene (10,65\%), dan Germacrene D (4,03\%). Hasil penelitian $\mathrm{Yu}$ et al. (2007), yang menggunakan metode microwave distillation and solid-phase microextraction (MD-SPME) terdapat 5 pula komponen kimia yang sama seperti halnya yang dihasilkan oleh Djafar (2010), namun jumlahnya berbeda pada setiap senyawa yang dihasilkan, seperti pada ar-Curcumene (3,59\%), Zingiberene (15,48\%), B-Sesquiphellandrene (5,54\%), Farnesene (2,51\%), dan Germacrene D $(0,64 \%)$.

Komposisi kimia minyak atsiri jahe merah dapat dipengaruhi oleh berbagai faktor, antara lain waktu panen, lingkungan 
tumbuh (ketinggian tempat, curah hujan, jenis tanah), dan keadaan rimpang (segar atau kering) (Mustafa \& Srivastava, 1990; Ali et al., 2008). Komponen kimia tertinggi hasil penelitian Djafar (2010), didominasi oleh senyawa ar-Curcumene, sedangkan komponen kimia tertinggi hasil penelitian $\mathrm{Yu}$ et al. (2007), didominasi oleh senyawa Zingieberene. Pada hasil penelitian ini, komponen senyawa kimia yang mendominasi adalah Zingiberene dengan jumlah lebih tinggi dibandingkan dengan Zingiberene yang dihasilkan Djafar (2010) dan Yu (2007). Tingginya kandungan zingiberene dalam minyak atsiri jahe yang dihasilkan pada penelitian ini disebabkan karena minyak atsiri jahe merah yang dihasilkan memberikan aroma harum khas jahe yang sangat kuat. Komponen utama minyak atsiri jahe yang menyebabkan bau harum adalah zingiberen dan zingiberol (Koswara, 1995). Minyak atsiri jahe merah mengandung zingiberene berkisar antara $19,61 \%-21,38 \%$ (Wulandari, 2010). Pada proses ekstraksi, faktor yang paling berpengaruh adalah rasio solute: solvent, dan waktu ekstraksi dimana semakin banyak pelarutnya dan semakin lama waktu ekstraksi akan semakin banyak camfen yang terekstrak sehingga semakin besar kadar zingiberennya (Handayani, 2015).

\section{KESIMPULAN}

Rasio pelarut heksan terhadap serbuk jahe merah yang menghasilkan rendemen tertinggi terdapat pada penggunaan rasio $1: 11(b / v)$ dengan rendemen ekstrak minyak atsiri jahe merah sebesar 6,695\%. Komponen kimia minyak atsiri jahe merah hasil analisis GC-MS terdiri atas zingiberene (31,47\%), 1-metil-4-(5-metilheksan-2-il) Benzen (22,46\%), B-Sesquiphellandren (21,51\%), B-Bisabolene (14,62\%), fernesene (7,70\%) dan Geranyl Acetate (2,24\%).

\section{DAFTAR PUSTAKA}

Ali, B. H., G. Blunden, M. O. Tanira, A. Nemmar. (2008). Some Phytochemical, Pharmacological and Toxicological Properties of Ginger (Zingiber officinale Roscoe): A review of recent research. Food and Chemical Toxicology. 46 : 409-420.

Budi, F.S. (2009). Pengambilan Oleoresin Dari ampas Jahe (Hasil Samping Penyulingan Minyak jahe) Dengan Proses Ekstraksi. Jurnal Teknik. 30(3).

Damayanti, A., \& Fitriana, E. A. (2012). Pemungutan minyak atsiri mawar (rose oil) dengan metode maserasi. Jurnal Bahan Alam Terbarukan, 1(2).

Djafar, F. (2010). Pengaruh Ukuran Partikel, SF Rasio dan Waktu Proses Terhadap Rendemen pada Hidrodistilasi Minyak Jahe. Jurnal Hasil Penelitian Industri. 23(2).

Fatriani. (2007). Rendemen dan Kualitas Minyak atsiri Jahe (Zingiber officinale Rose). Jurnal Hutan Tropis Borneo. 8(20) : 8 - 16.

Handayani, D. (2015). Peningkatan Kadar Zingiberen Dalam Minyak Jahe Dengan Ekstraksi Cair-Cair. Prosiding SNST ke-6 Tahun 2015 Semarang: Fakultas Teknik Universitas Wahid Hasyim.

Koswara, S. (1995). "Jahe dan Hasil Olahannya". Jakarta : Pustaka Sinar harapan.

Kurniasari, L. (2008). Kajian Ekstraksi Minyak Jahe Menggunakan Microwave Assisted Ekstraction (MAE). Momentum. 4(2): 47-52. 
Mustafa, T., K.C. Srivastava. (1990). Ginger (Zingiber officinale) in Migraine Headache. J. Ethnopharmacol. 29: 267-273.

Purwanto, H. (2010). Pengembangan Microwave Assisted Extractor (MAE) Pada Produksi Minyak Jahe Dengan Kadar Zingeberene Tinggi. Momentum. 6(2): 9-16.

Rumondang, B. (2004). Esterifikasi Patchouli Alkohol Hasil Isolasi Dari Minyak Daun Nilam (Patchouli Oil). library.usu.ac.id/download/fmipa/kimiarumondang2.pdf , diunduh pada tanggal 5 Januari 2018.

Winarsi, D. (2014). Isolasi dan Identifikasi Komponen Kimia Minyak Atsiri Dari Daun, Batang dan Bunga Tumbuhan Salembangu (Melissa Sp.). Skripsi. Palu: Program Studi Kimia Fakultas Matematika dan IImu Pengetahuan Alam Universitas Tadulako.

Wulandari, Y.W. (2010). Karakteristik Minyak Atsiri Beberapa Varietas Jahe (Zingiber officinale). Jurnal Kimia dan Teknologi. 43-50.

Yu, Y., T. Huang, B. Yang, X. Liu, G. Duan. (2007). Development of Gas Chromatography-Mas Spectrometry with Microwave Distillation and Simultaneous Solid - Phase Micro Extraction for Rapid Determination of Volatile Constituents in Ginger. Journal of Pharmaceutical and Biomedical Analysis. 43: 24-31. 